\title{
Effects of body size on suspension feeding and energy budgets of the pearl oysters Pinctada margaritifera and $P$. maxima
}

\author{
H. Yukihira ${ }^{1}$, D. W. Klumpp ${ }^{2, *}$, J. S. Lucas ${ }^{1}$ \\ ${ }^{1}$ Department of Aquaculture, School of Biological Sciences, James Cook University, Townsville, Queensland 4811, Australia \\ ${ }^{2}$ Australian Institute of Marine Science, PMB 3, Townsville MC, Queensland 4810, Australia
}

\begin{abstract}
This study compared suspension feeding, assimilation efficiency, respiration and excretion, and energy budgets (= scope for growth, SFG) in relation to body size in 2 pearl oysters, Pinctada margaritifera and P. maxima, at a low food concentration (ca 5000 cells $\mathrm{ml}^{-1}$ Tahitian Isochrysis galbana). Clearance rate (CR), respiration rate (R) and ammonia excretion rate (E) were strongly correlated with body size $(p<0.001)$ in both species, with exponents of 0.60 and 0.61 (CR), 0.44 and $0.56(R)$, and 0.64 and 0.78 (E), respectively, for P. margaritifera and $P$. maxima. CR did not differ significantly between the species, but absorption efficiency, which was unrelated to size, was significantly greater in P. maxima ( 57.5 vs $51 \%, \mathrm{p}<0.05$ ). There was, however, no significant difference in absorbed energy (AE) between the species. Respired energy (RE) and excreted energy (EE) as proportions of AE were significantly lower $(\mathrm{p}<0.01)$ in $P$. maxima of $0.1 \mathrm{~g}$ dry soft tissue wt (ca $36 \mathrm{~mm}$ shell height, SH). The former was 0.36 compared to 0.58 in $P$. margaritifera of the same size. Thus, $P$. maxima of $0.1 \mathrm{~g}$ dry soft tissue wt exceeded P. margaritifera of the same size in SFG, which accords with the former species' more rapid early growth. Both species of pearl oysters have a high ability to acquire energy under low phytoplankton conditions. Both species are exceptional bivalves in terms of energy fluxes, with clearance rates of 50 to $100 \mathrm{l} \mathrm{h}^{-1}$ in large oysters of $150+\mathrm{mm} \mathrm{SH}$. They show among the highest $\mathrm{CR}, \mathrm{R}, \mathrm{E}$ and SFG values recorded for bivalves (using $1 \mathrm{~g}$ dry soft tissue wt as a standard size). The largest giant clam, Tridacna gigas, is one tropical bivalve with comparable SFG. It, however, is dependent on energy from autotrophy as well as heterotrophy to achieve its high SFG.
\end{abstract}

KEY WORDS: Pearl oyster Pinctada margaritifera Pinctada maxima - Energy budget - Size - Scope for growth Clearance rate Physiology

\section{INTRODUCTION}

The black-lip pearl oyster Pinctada margaritifera Linnaeus and silver-lip pearl oyster $P$. maxima Jameson are among the largest Pinctada species (family Pteriidae). P. margaritifera grows to $100-120 \mathrm{~mm}$ in shell height at 2 yr of age (Coeroli et al. 1984, Sims 1993), while $P$. maxima grows to $100-160 \mathrm{~mm}$ (Sagara $\&$ Takemura 1960). The maximum shell height of $P$. margaritifera is 140 to $170 \mathrm{~mm}$ (Coeroli 1983), while that of $P$. maxima is 200 to $250 \mathrm{~mm}$ (Sagara \& Takemura 1960, Gervis \& Sims 1992). Both species are com-

\footnotetext{
-Addressee for correspondence.
}

E-mail:d.klumpp@aims.gov.au mercially important as the basis of cultured pearl industries.

The natural habitats of Pinctada margaritifera and $P$. maxima are different. P. margaritifera typically inhabits the oligotrophic waters of atoll lagoons and coral reefs. $P$. maxima typically inhabits regions of soft substrate adjacent to mainland islands and continents, and its habitats are characterised by higher amounts of terrigenous sediments, nutrient inputs and productivity levels than those of $P$. margaritifera (Gervis \& Sims 1992). It may be hypothesised from these differences in habitats that there are major differences between the suspension feeding processes of the 2 species. $P$. margaritifera should have higher clearance rates and feed more effectively at low phytoplankton levels than $P$. 
maxima, but the latter species should be able to deal more effectively with suspended inorganic particles. The differences between these species in early growth rate and maximum size also suggest differences in other physiological processes and in their energy budgets.

In making comparisons of physiological processes and energy budgets between species and within species, it is essential that these are related to body size. Rates of physiological processes increase as power relationships with increasing body size, but rates per unit body mass tend to decrease with increasing size. These effects of body size on physiological rates and energy budgets have been well documented for temperate marine bivalves, especially mussels (Family Mytilidae) (e.g. Widdows 1978a, b, Griffiths \& King 1979a, b, Navarro \& Winter 1982). There have, however, been fewer studies on body size effects on physiological processes and energy budgets in tropical marine bivalves; that is, with the exception of giant clams (Family Tridacnidae) (Klumpp et al. 1992, Klumpp \& Griffiths 1994, Klumpp \& Lucas 1994, Hawkins \& Klumpp 1995). There have been 4 studies of the effects of body size on various physiological processes in Pinctada species (Itoh 1976. Sugiyama \& Tomori 1988, Stiger 1993, Ward \& MacDonald 1996), but none has considered complete energy budgets.

The aims of this study were therefore: (1) to quantify the physiological processes of suspension feeding, respiration, assimilation and excretion in relation to body size of Pinctada margaritifera and $P$. maxima; (2) from these parameters, to calculate energy budgets over a range of body sizes for $P$. margaritifera and $P$. maxima; and then (3) to relate these energy budgets to the observed differences in their growth rates, maximum sizes and habitat differences.

The energy budgets of the 2 species were summarised as scope for growth (SFG), which is the energy available to an animal for growth (plus reproduction in sexually mature animals). SFG has been used extensively for intraspecific and interspecific comparisons in marine bivalves, especially as a stress and pollution indicator (e.g. Bayne \& Newell 1983, Bayne et al. 1985, Griffiths \& Griffiths 1987, Widdows et al. 1990, 1995, 1997).

\section{MATERIAL AND METHODS}

Pearl oysters. The Pinctada margaritifera used in this study were hatchery-reared and field specimens from a long-line culture system at Orpheus Island Research Station, North Queensland, Australia (18 $37^{\prime}$ $\left.\mathrm{S}, 146^{\circ} 30^{\prime} \mathrm{E}\right)$. The $P$. maxima were hatchery-reared specimens from long-line farms located at Hinchin- brook Channel $\left(18^{\circ} 18^{\prime} \mathrm{S}, 146^{\circ} 06^{\prime} \mathrm{E}\right)$ and Fitzroy Island $\left(16^{\circ} 57^{\prime} \mathrm{S}, 146^{\circ} 00^{\prime} \mathrm{E}\right)$, North Queensland. All oysters were kept in frames with net pockets suspended at about $1.5 \mathrm{~m}$ depth beneath a pontoon in a sheltered bay at the Australian Institute of Marine Science, North Queensland $\left(19^{\circ} 15^{\prime}\right.$ S, $\left.147^{\circ} 05^{\prime} \mathrm{E}\right)$. They were acclimated there for at least 1 mo before use in experiments. The shells of all oysters were thoroughly cleaned of epibiota during the acclimation period. They were cleaned again the day before use in experiments. Seawater temperatures in the field where the oysters were held varied from 25 to $28^{\circ} \mathrm{C}$ over the study period. All experiments were conducted at $28 \pm 1{ }^{\circ} \mathrm{C}$.

Morphometrics. Shell height ( $\mathrm{SH}, \mathrm{mm})$, the greatest distance from the umbo to the base of a finger or growth process (Sims 1993), was recorded as the routine non-destructive measure of size for the experiments. Physiological rates and energy budgets were calculated for 3 classes of oysters, corresponding to $0.1 \mathrm{~g}$ (small), $1 \mathrm{~g}$ (medium) and $10 \mathrm{~g}$ (large) dry soft tissue weight ( $w t)$. Dry soft tissue wt of each experimental specimen was calculated from SH using SH-dry soft tissue wt relationships. These relationships were determined by sacrificing selected oysters from across a wide size range covering 0.1 to $10 \mathrm{~g}$ dry soft tissue wt. Extruding byssal threads were carefully cut of before sacrifice. The soft tissue was removed, cut into pieces and dried at $60^{\circ} \mathrm{C}$ to obtain dry soft tissue mass

The calorific values of soft tissue and shell were determined using a Parr 1421 semi-micro bomb calorimeter. Four individuals of each species were sacrificed. All soft tissues including internal byssal threads were removed, chopped into small pieces and dried. Samples (20 to $40 \mathrm{mg}$ ) from each homogenised tissue sample were analysed. Calcium carbonate from the shell was dissolved in $13 \mathrm{~N} \mathrm{HCl}$, and the remaining matrix was rinsed with distilled water, dried, homogenised, and then analysed for calorific values following Griffiths \& King (1979b).

Algal suspensions. During experiments the oysters were fed with 5000 cells $\mathrm{ml}^{-1}\left(=0.5 \mathrm{mg}\right.$ dry weight $\mathrm{l}^{-1}$ ) suspensions of the phytoflagellate Isochrysis aff. galbana Tahitian ( $\mathrm{T}$-Iso), which was harvested during its logarithmic phase of growth. This concentration level represents oligotrophic coral reef waters. The calorific value of T-Iso was determined using a Parr 1421 semimicro bomb calorimeter (following Whyte 1987) as $20.27 \mathrm{~J} \mathrm{mg}^{-1}$ dry soft tissue wt.

Clearance rates. The volume of water each oyster cleared of particulate material (CR, 1 oyster $^{-1} \mathrm{~h}^{-1}$ ) was determined using a flow-through system, in which $0.45 \mu \mathrm{m}$ filtered seawater containing the food suspension flowed through 4 chambers (according to Widdows 1985). Three of the chambers contained an oyster, while the fourth acted as a control. From the flow 
rate $\left(\mathrm{F}, \mathrm{l} \mathrm{h}^{-1}\right)$, and the concentrations of food particles immediately surrounding each oyster $\left(\mathrm{C}_{0}\right)$, in the outflow of control chamber $\left(C_{1}\right)$ and in the outflow of each experimental chamber $\left(C_{2}\right)$, clearance rates were calculated using the following expression, after Hildreth \& Crisp (1976):

$$
\text { CR }\left(1 \text { oyster }^{-1} h^{-1}\right)=F\left(C_{1}-C_{2}\right) / C_{0}
$$

Four sets of chambers with volumes of 2, 4,6 and 181 were used for oysters of different sizes. A constant flow rate between 12 and $35 \mathrm{l} \mathrm{h}^{-1}$, depending on size of the oysters, was maintained during the experiment. Oysters were placed in the flow-through chambers and kept undisturbed. Measurements were commenced at least $1 \mathrm{~h}$ after the oysters showed sufficient gape to be feeding. Concentrations of T-Iso were then measured at $1 \mathrm{~h}$ intervals (means of 5 counts) using a Coulter counter (Multisizer) with a $140 \mu \mathrm{m}$ orifice tube. The main principles and advantages of the flow-through system for CR determination were described by Widdows (1985).

Ration level of each oyster was determined by ca.culating a mean value of 5 counts of $C_{0}$. Since the ration

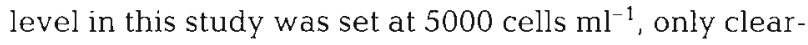
ance rates obtained from oysters fed with ration levels of $5000 \pm 1000$ cells $\mathrm{ml}^{-1}$ were used for energy calculations. Both species did not produce pseudofaeces at this ration level. CRs for oysters of each size class $(0.1$, 1 and $10 \mathrm{~g}$ dry soft tissue $w \mathrm{t}$ ) were calculated from CRsize regression equations. Ingested energy (IE, J oyster ${ }^{-1} \mathrm{~h}^{-1}$ ) was then calculated as the product of CR and the energy content of $\mathrm{T}$-Iso.

Absorption efficiency and absorbed energy. The percentage of consumed food that was absorbed by each oyster's digestive system was determined by comparing the fraction of faeces lost on ashing with the fraction of samples of food suspension lost on ashing. Absorption efficiency (abs.eff., \%) was then calculated according to the equation of Conover (1966):

$$
\text { abs.eff. }(\%)=100 \times(f-e) /(1-e) f
$$

where $f$ and $e$ are the fractions of food and faeces lost on ashing, respectively. Faeces were collected from the chambers on completion of the measurements of CR and excretion rate (see below). Faeces were filtered onto pre-rinsed and ashed GFC filter papers, rinsed with distilled water, dried, and ashed at $450^{\circ} \mathrm{C}$ for $5 \mathrm{~h}$. Food samples (T-Iso), consisting of 2 l samples of water from the control chamber, were treated in the same way.

Absorbed energy (AE) of individual oysters was calculated as a product of energy of food, CR and abs.eff.

Respiration rates. Before respiration experiments, oysters were fed with T-Iso at a concentration of $5000 \pm$ 1000 cells $\mathrm{ml}^{-1}$ for at least $2 \mathrm{~h}$ in a $100 \mathrm{l}$ tank with aera- tion. They were then placed individually into 3 sealed measurement chambers ( 2 or 13 l, according to oyster size) with $0.45 \mu \mathrm{m}$ filtered seawater and T-Iso (5000 to 6000 cells $\mathrm{ml}^{-1}$ ). At the same time a sealed chamber of the same size as the measurement chamber with food and no oyster was set up as a control. Water in each chamber was mixed by a magnetic stirrer. Oxygen concentration in each chamber was measured at $5 \mathrm{~min}$ intervals using a YSI dissolved oxygen meter (model 55). Preliminary research revealed that both species took at most $15 \mathrm{~min}$ to stabilise in the conditions. The food suspension in the chambers was expected to be quickly depleted due to feeding. Recordings were restricted to the first 10 to $30 \mathrm{~min}$ after the initial equilibration period, depending on the body size. Respiration rate $\left(\mathrm{R}, \mathrm{ml} \mathrm{O} \mathrm{O}_{2}\right.$ oyster $\left.^{-1} \mathrm{~h}^{-1}\right)$ was determined according to Widdows (1985). Respired energy (RE, J oyster ${ }^{-1}$ $\mathrm{h}^{-1}$ ) of each size class was then calculated from the REsize regression equations and $1 \mathrm{ml} \mathrm{O}_{2}=20.33 \mathrm{~J}$ (Crisp 1971).

Excretion rate. The rate of ammonia excretion ( $E, \mu \mathrm{g}$ $\mathrm{NH}_{4}-\mathrm{N}$ oyster ${ }^{-1} \mathrm{~h}^{-1}$ ) was determined after completion of clearance rate measurements. Oysters were carefully transferred to another set of 4 chambers containing $0.45 \mu \mathrm{m}$ filtered seawater. Three of these contained an oyster, while the fourth acted as a control. Oysters were kept undisturbed for up to 60 min according to the volumes of water and the oyster's body size. Duplicate samples $(10 \mathrm{ml})$ were collected from each chamber, passed through a $0.45 \mu \mathrm{m}$ filter and frozen until assaying. Analyses for ammonia content were conducted using the phenol-hypochlorite method of Solorzano (1969). E was determined following Widdows (1985). Excreted energy (EE, J oyster ${ }^{-1} \mathrm{~h}^{-1}$ ) of each size class was then calculated from the E-size regression equations and assuming $1 \mathrm{mg} \mathrm{NH}_{4}-\mathrm{N}=24.87 \mathrm{~J}$ (Widdows \& Johnson 1988).

Scope for growth. The energy that oysters have available for growth and reproduction, scope for growth ( $\mathrm{SFG}, \mathrm{J} \mathrm{h}^{-1}$ ), was determined using the equation:

$$
\operatorname{SFG}\left(\mathrm{J} \mathrm{h}^{-1}\right)=\mathrm{AE}-(\mathrm{RE}+\mathrm{EE})
$$

(Warren \& Davis 1967, Widdows 1985)

SFGs for each species and size class were determined from calculated $A E, R E$ and EE values. The SFG values relate to the experimental temperature $28 \pm 1^{\circ} \mathrm{C}$ which is an approximate mean temperature for the field.

Data analysis. As expected, $C R, A E, R$ and $E$ varied markedly with oyster size. Variations in these parameters for species were examined using ANCOVA with body size as the covariate. Absorption efficiency (abs.eff.) was independent of oyster size (from regression analysis), thus the effect of species on abs.eff. was tested using 1-way ANOVA. 
Table 1. Morphometric relationships $\left(y=a x^{0}\right)$ for Pinctada margaritifera and $P$ maxima, where $x$ is shell height $(\mathrm{mm})$ and $y$ is mass of shell or tissue ( $g$ dry weight)

\begin{tabular}{|llcccc|}
\hline Species & $y$ & $a$ & $b$ & $\mathrm{r}^{2}$ & $\mathrm{n}$ \\
\hline P. margaritifera & Tissue & $9.93 \times 10^{-7}$ & 3.21 & 0.98 & 19 \\
& Shell & $8.92 \times 10^{-6}$ & 3.45 & 0.99 & 25 \\
P. maxima & Tissue & $3.13 \times 10^{-6}$ & 2.87 & 0.99 & 14 \\
& Shell & $1.44 \times 10^{-5}$ & 3.31 & 0.99 & 17
\end{tabular}

\section{RESULTS}

\section{Morphometrics}

The relationships between dry soft tissue weight (W), shell weight and shell height ( $\mathrm{SH}$ ) for the 2 species are shown in Table 1. As expected, on the basis that weight is approximately proportional to (length) ${ }^{3}$, the exponent $b$ values are close to 3 . There were very close fits $\left(\mathrm{r}^{2}=\right.$ 0.98 and 0.99 ) for the regressions between $W$ and $\mathrm{SH}$.

The 3 dry soft tissue weights used as standards in this study, small $(0.1 \mathrm{~g})$, medium (1 g) and large (10 g), corresponded to approximately 36,74 and $152 \mathrm{~mm} \mathrm{SH}$ in Pinctada margaritifera, and 37,83 and $185 \mathrm{~mm} \mathrm{SH}$ in $P$. maxima, respectively.

The mean energy values $(n=4)$ of soft tissue for Pinctada margaritifera and P. maxima were $16.22 \pm$ 0.21 and $15.41 \pm 0.24 \mathrm{~J} \mathrm{mg}^{-1}$ dry $w t$, respectively. The energy values of shell $(\mathrm{n}=4)$ for $P$. margaritifera and $P$. maxima were $0.32 \pm 0.002$ and $0.30 \pm 0.059 \mathrm{~J} \mathrm{mg}^{-1}$ dry wt, respectively.

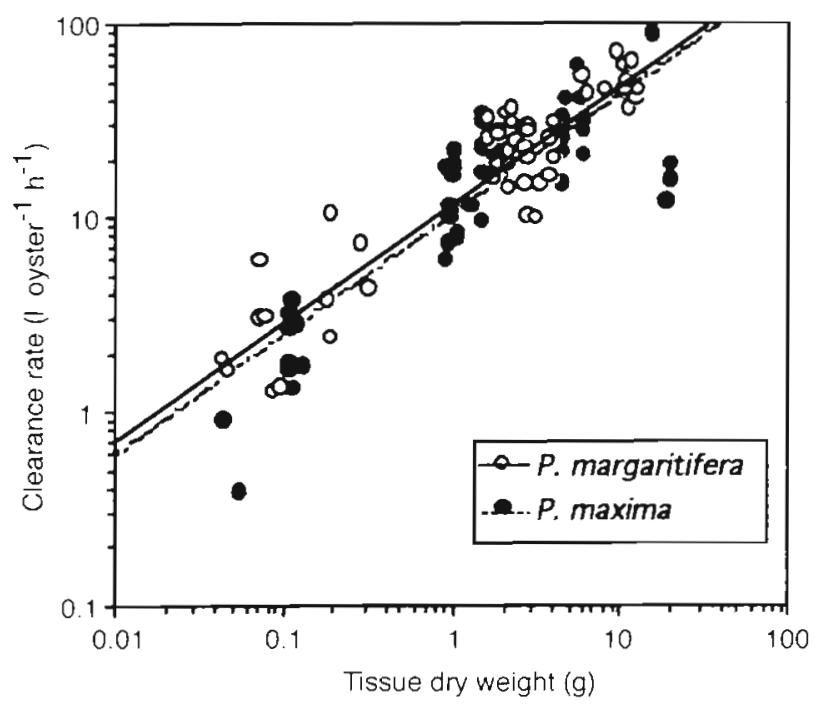

Fig. 1. Relatıonships between clearance rates and dry soft tissue weight for Pinctada margaritifera and $P$. maxima feeding on Isochrysis aff. galbana Tahitian (ca 5000 cells m].-1). Each data point is the rate for a single oyster. Regression equations are in the text
Table 2. Summary of ANCOVA testing for similarity in slopes and intercepts of regression lines of clearance rate (CR), absorbed energy (AE), respiration rate $(R)$ and excretion rate $(E)$ between species of pearl oysters (Pinctada margaritifera and $P$. maxima) with dry tissue weight as the covariate. NS: not significant at $p<0.05 ; " p<0.05 ; \cdots p<0.001$

\begin{tabular}{|lcccc|}
\hline \multirow{2}{*}{ Source of variation } & \multicolumn{4}{c}{ Variance } \\
& $\mathrm{CR}$ & $\mathrm{AE}$ & $\mathrm{R}$ & $\mathrm{E}$ \\
\hline Slopes & $\ldots$ & $\ldots$ & $\ldots$ & $\ldots$ \\
Weight & $\mathrm{NS}$ & $\mathrm{NS}$ & $\mathrm{NS}$ & $\mathrm{NS}$ \\
$\begin{array}{l}\text { Species } \\
\text { Weight } \times \text { Species }\end{array}$ & $\mathrm{NS}$ & $\mathrm{NS}$ & $\cdot$ & $\cdot$ \\
$\begin{array}{l}\text { Intercepts } \\
\text { Weight } \\
\text { Species }\end{array}$ & $\ldots$ & $\ldots$ & & \\
\hline
\end{tabular}

\section{Clearance rate (CR), absorption efficiency (abs.eff.) and absorbed energy (AE)}

CRs of Pinctada margaritifera and $P$. maxima were closely correlated with body size (Fig. 1). Relationships between CR $\left(\mathrm{l} \mathrm{h}^{-1}\right)$ and body size (W, g) are described by the functions:

$$
\begin{array}{ll}
\text { P. margaritifera } & \\
\mathrm{CR}=12.34 \times 0.604 \mathrm{~W} & \left(\mathrm{r}^{2}=0.86, \mathrm{n}=52, \mathrm{p}<0.001\right) \\
\text { P. maxima } & \\
\mathrm{CR}=10.73 \times 0.617 \mathrm{~W} & \left(\mathrm{r}^{2}=0.71, \mathrm{n}=54, \mathrm{p}<0.001\right)
\end{array}
$$

Neither slopes nor intercepts of the regressions of $\mathrm{CR}$ on body size differed significantly between species

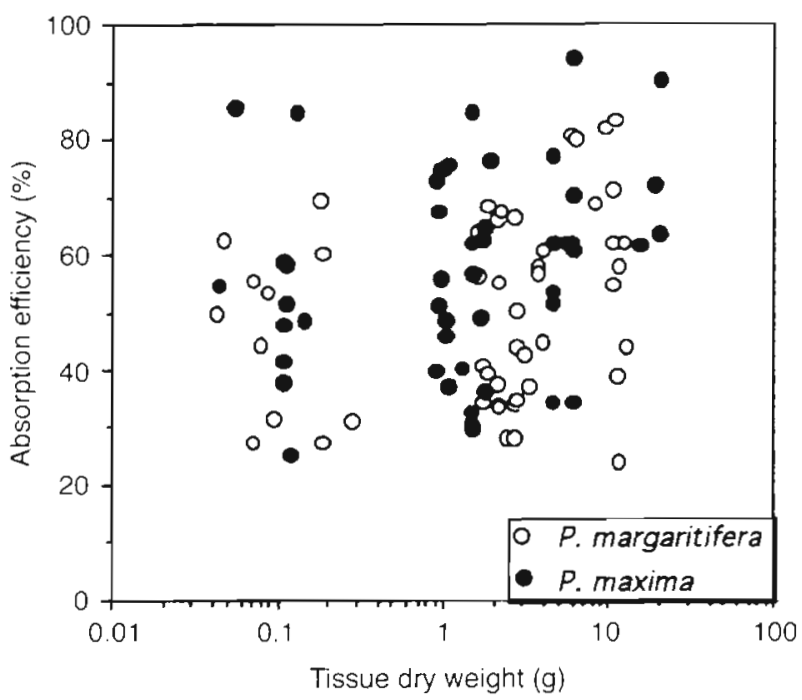

Fig. 2. Absorption efficiency (abs.eff.) in Pinctada margaritifera and $P$. maxima feeding on Isochrysis aff. galhana Tahi-

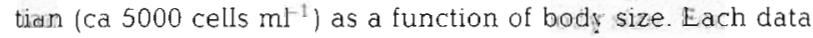
point is abs.eff. for a single oyster 
Table 3. Summary of clearance rate (CR), absorption efficiency (abs.eff.), absorbed energy (AE), respired energy (RE) and excreted energy (EE) for Pinctada margaritifera and P. maxima feeding on Isochrysis aff. galbana Tahitian at a density of 5000 cells ml $^{-1}$ Figures in brackets represent \% of total absorbed energy. Significant differences in RE and EE of each body size between species are shown individually; NS: not significant at $p<0.05 ; " p<0.05, \cdots p<0.01$. Scope for growth (SFG), which is calculated as $A E-(R E+E E)$, and percentage change in whole body energy per day (as relative SFG) are also shown

\begin{tabular}{|c|c|c|c|c|}
\hline \multirow[t]{2}{*}{ Parameter } & \multirow[t]{2}{*}{ Species } & \multicolumn{3}{|c|}{ Body size ( $g$ tissue dry wt) } \\
\hline & & 0.1 (small) & 1 (medium) & 10 (large) \\
\hline CR $\left(1 h^{-1}\right)$ & Both species & 2.8 & 11.5 & 47.1 \\
\hline \multirow[t]{2}{*}{ abs.eff. $(\%)$} & P. margaritifera & 51.0 & 51.0 & 51.0 \\
\hline & P. maxima & 57.5 & 57.5 & 57.5 \\
\hline $\operatorname{AE}\left(J h^{-1}\right)$ & Both species & $13.2(100)$ & $58.9(100)$ & $263.1(100)$ \\
\hline \multirow[t]{2}{*}{$\operatorname{RE}\left(\mathrm{J} \mathrm{h}^{-1}\right)$} & P. margaritifera & $7.7 \cdot(58.3)$ & $21.1^{\text {NS }}(35.5)$ & $58.0^{N S}(21.9)$ \\
\hline & P. maxima & $4.8(36.3)$ & $17.4(29.3)$ & $63.4(23.0)$ \\
\hline \multirow[t]{2}{*}{$E E\left(J h^{-1}\right)$} & P. margaritifera & $0.46^{\bullet}(3.5)$ & $2.0^{\mathrm{NS}}(3.4)$ & $8.9^{\mathrm{NS}}(3.4)$ \\
\hline & P. maxima & $0.27(2.1)$ & $1.8(3.1)$ & $12.2(4.6)$ \\
\hline$S F G=A E-(R E+E E)$ & P. margaritifera & 5.0 & 35.8 & 196.2 \\
\hline$\left(\mathrm{J} \mathrm{h}^{-1}\right)$ & P. maxima & 8.1 & 39.7 & 187.5 \\
\hline Relative SFG = & P. margaritifera & 5.3 & 3.5 & 1.8 \\
\hline $\begin{array}{l}\text { percentage change } \\
\text { in body energy }\left(\% \mathrm{~d}^{-1}\right)\end{array}$ & P. maxima & 8.8 & 3.8 & 1.5 \\
\hline
\end{tabular}

(Table 2). Therefore, the common slope and intercept values were recalculated using all data $(n=106)$ and expressed as follows:

$$
\mathrm{CR}=11.47 \times 0.613 \mathrm{~W} \quad\left(\mathrm{r}^{2}=0.78, \mathrm{n}=106, \mathrm{p}<0.001\right)
$$

Using this regression line, CR of each size class was

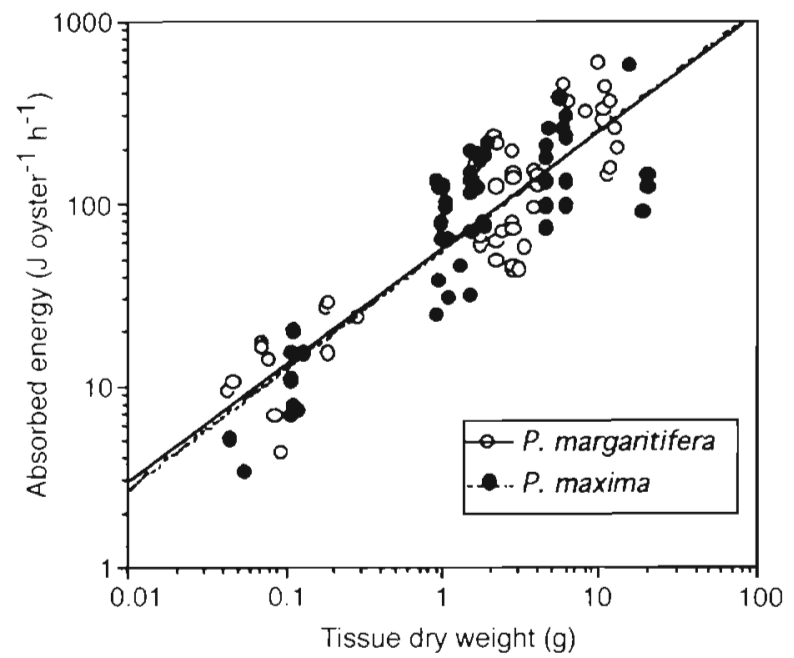

Fig. 3. Relationships between absorbed energy (AE) and body size for Pinctada margaritifera and P. maxima feeding on

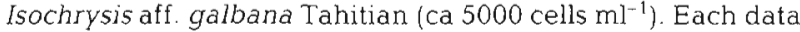
point is AE for a single oyster. Regression equations are in the text determined (Table 3). The CRs of the pearl oysters of $10 \mathrm{~g}$ dry soft tissue wt are substantial in larger pearl oysters, being $47 \mathrm{l} \mathrm{h}^{-1}$.

Absorption efficiency (abs.eff., \%) of each species was independent of body size (Fig. 2). Comparison of mean abs.eff. values for both species revealed that Pinctada maxima absorbed T-Iso food particles with a significantly greater efficiency than $P$. margaritifera (Table 4, ANOVA, p < 0.05).

Absorbed energy (AE) of Pinctada margaritifera and $P$. maxima was closely correlated with body size (Fig. 3):

$$
\begin{aligned}
& \text { P. margaritifera } \\
& \mathrm{AE}=59.50 \times 0.641 \mathrm{~W} \quad\left(\mathrm{r}^{2}=0.80, \mathrm{n}=50, \mathrm{p}<0.001\right) \\
& \text { P. maxima } \\
& \mathrm{AE}=57.30 \times 0.656 \mathrm{~W} \quad\left(\mathrm{r}^{2}=0.73, \mathrm{n}=49, \mathrm{p}<0.001\right)
\end{aligned}
$$

Slopes and intercepts of the regressions did not dif-

Table 4. Mean ( \pm SE) absorption efficiencies (abs.eff.) for Pinctada margaritifera and $P$. maxima feeding on Isochrysis aff. galbana Tahitian at a density of 5000 cells $\mathrm{ml}^{-1}$. The 2 species have significantly different abs.eff. values (ANOVA, $p<0.05$ )

\begin{tabular}{|lccc|}
\hline Species & Size range $(\mathrm{mm})$ & $\mathrm{n}$ & abs.eff. $(\%)$ \\
\hline P. margaritifera & $27.8-164.2$ & 50 & $51.0 \pm 2.3$ \\
P. maxima & $27.8-236.7$ & 51. & $57.5 \pm 2.4$ \\
\hline
\end{tabular}


fer significantly between the 2 species (Table 2), hence the common regression line was determined:

$$
A E=58.9 \times 0.650 \mathrm{~W} \quad\left(\mathrm{r}^{2}=0.77, \mathrm{n}=99, \mathrm{p}<0.001\right)
$$

AE for each size class is shown in Table 3 .

\section{Respiration}

Respiration rates $(\mathrm{R})$ of both Pinctada margaritifera and $P$. maxima depended strongly on body size (Fig. 4), as quantified by the equations:

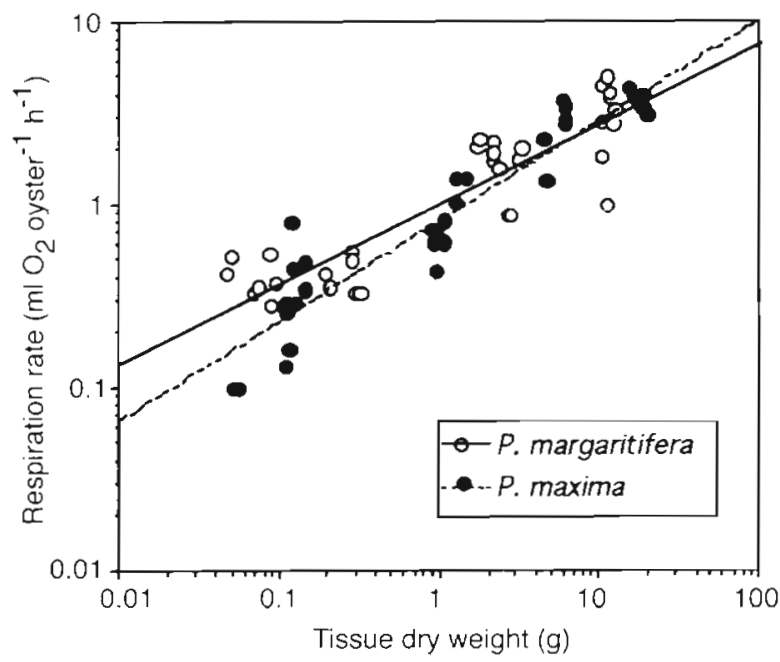

Fig. 4. Relationships between respiration rates and body size for Pinctada margaritifera and P. maxima feeding on Isochrysis aff. galbana (ca 5000 cells $\mathrm{ml}^{-1}$ ). Each data point is the rate

for a single oyster. Regression equations are in the text

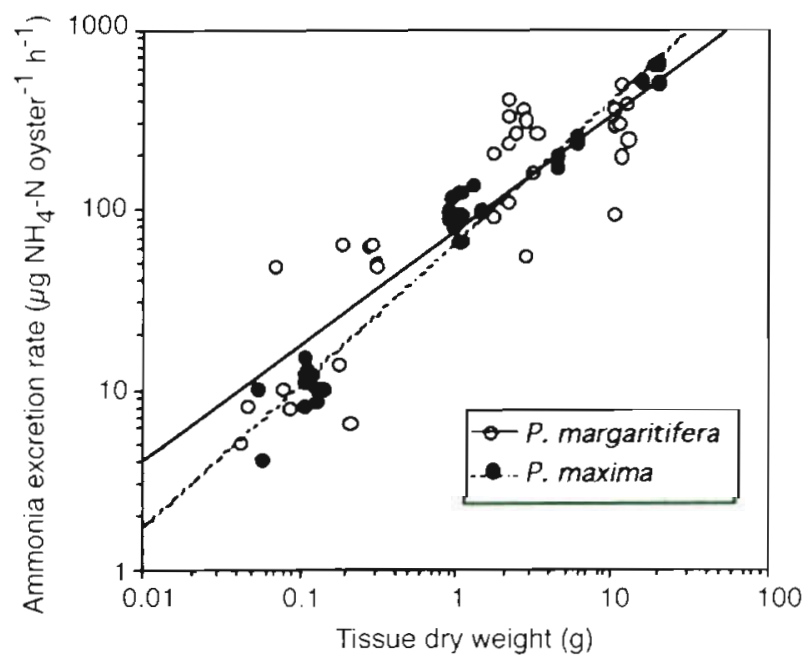

Fig. 5. Relationships between ammonia excretion rates and body size for Pinctada margaritifera and P. maxima feeding on Isochrysis aff. galbana Tahitian (ca 5000 cells m] ${ }^{-1}$ ). Each data point is the rate for a single oyster. Regression equations are in the toxt

$$
\begin{array}{ll}
\text { P. margaritifera } & \\
\mathrm{R}=1.039 \times 0.439 \mathrm{~W} & \left(\mathrm{r}^{2}=0.81, \mathrm{n}=34, \mathrm{p}<0.001\right) \\
P . \text { maxima } & \\
\mathrm{R}=0.857 \times 0.561 \mathrm{~W} & \left(\mathrm{r}^{2}=0.87, \mathrm{n}=33, \mathrm{p}<0.001\right)
\end{array}
$$

Slopes of these equations differed significantly between species (Table 2 , ANCOVA $p<0.05$ ). Since the regression lines intersected, points on the 2 regression lines equivalent to $0.1,1,10 \mathrm{~g}$ dry soft tissue wt were compared between the species using a 2-tailed test (Zar 1996), and only small oysters (0.1 g dry soft tissue $w t)$ had significantly different Rs $(p<0.01)$. The respired energy ( $R E$ ) of each size class is shown in Table 3. Metabolic cost is 1.6 times higher in small Pinctada margaritifera than in $P$. maxima ( $=7.7$ vs $4.8 \mathrm{~J}$ $\left.\mathrm{h}^{-1}\right)$. RE as a percentage of AE was 22 to 58 and 23 to $36 \%$ for $P$. margaritifera and $P$. maxima, respectively.

\section{Ammonia excretion}

The excretion rate $(E)$ in relation to body size is shown in Fig. 5 and described by the equations:

$$
\begin{array}{ll}
\text { P. margaritifera } & \\
\mathrm{E}=81.37 \times 0.642 \mathrm{~W} & \left(\mathrm{r}^{2}=0.74, \mathrm{n}=32, \mathrm{p}<0.001\right) \\
\text { P. maxima } & \\
\mathrm{E}=72.83 \times 0.789 \mathrm{~W} & \left(\mathrm{r}^{2}=0.96, \mathrm{n}=30, \mathrm{p}<0.001\right)
\end{array}
$$

Slopes of E against body size differed significantly between species (Table 2, ANCOVA, $p<0.05$ ). The excreted energy (EE) of each size class is expressed in Table 3. Small (0.1 g) Pinctada margaritifera excreted more energy than $P$. maxima ( $p<0.05$ ), but differences in EE were not significant at larger body sizes. Proportions of EE to AE for P. margaritifera and $P$. maxima were very small, being 3.4 to 3.5 and 2.1 to $4.6 \%$, respectively.

\section{DISCUSSION}

Scope for growth (SFG) is calculated for both species of pearl oysters in Table 3. Given that the 2 species absorbed the same amount of energy from food (AE) and that Pinctada margaritifera of $0.1 \mathrm{~g}$ dry soft tissue wt had comparatively higher respiration and excretion energy expenditure, $P$. maxima of this size had significantly higher SFG than $P$. margaritifera. However, larger individuals of these species ( 1 to $1.0 \mathrm{~g}$ dry soft tissue wt) show similar SFG. Change in body energy per day (SFG) as a percentage of whole body energy (relative SFG) was calculated to compare growth potentiality (Table 3). Small oysters showed the highest relative SFG and this percentage change decreased markedly with increasing body size. Relative SFG data indicate 
that small $P$. maxima grow faster than $P$. margaritifera, but in the former species the growth rate decreases with size more rapidly than in the latter. P. maxima of 0.1 to $1 \mathrm{~g}$ dry soft tissue wt (ca 36 to $80 \mathrm{~mm} \mathrm{SH}$ ) maximises SFG compared with P. margaritifera of the same size because it uses less energy for respiration and excretion (Table 3). Given that both species are sexually immature over this size range, differences in excess energy will be available for somatic growth. This explains the greater growth rate observed until 2 yr of age for P. maxima (Sagara \& Takemura 1960, Coeroli et al. 1984, Sims 1993). In contrast, there are no differences between species in the SFG data for $10 \mathrm{~g}$ oysters (Table 3 ). This is in apparent conflict with the observed larger maximum size reached by $P$. maxima. However, both species become sexually mature at a dry tissue wt of about $2 \mathrm{~g}$, and at that stage the SFG energy is required for both somatic growth and gamete production. We suggest that $P$. margaritifera does not reach the size of $P$. maxima because it commits relatively more energy to gamete production. (There are no data on gamete production in these species.) These observations are, however, based on the estimation of SFG using a food source of a single microalga at a relatively low cell concentration, and thus some caution is needed at this stage in extrapolating to field conditions

Jørgensen $(1990,1996)$ concluded that the capacity for water processing in bivalves is evolutionarily adapted to the concentrations of suspended food, primarily phytoplankton, that prevail in their biotope during the productive seasons of the year. We hypothesised from differences in habitats of the 2 species that Pinctada margaritifera would have a higher clearance rate (CR) under oligotrophic conditions; however, there was no difference in CR between the 2 species in the simulated oligotrophic conditions of this study (Fig. 1). This, together with the high SFG for $P$. maxima of all sizes and substantially higher SFG for $P$. maxima than $P$. margaritifera at small size (Table 3 ), suggests that $P$. maxima can grow and reproduce under conditions of low food suspensions.

Kailola et al. (1993) described how Pinctada maxima inhabits a variety of substrates, from mud, sand, gravel, seagrass beds to deepwater reefs, living beside sponges, soft corals and whip corals. The effects of food concentration, both natural and cultured, on suspension feeding and energy budgets in the 2 pearl oyster species will be examined in further studies.

Respired energy (RE) is an important component of the energy budget of pearl oysters, especially in small oysters. In comparison, excreted energy losses (EE) represent a small proportion of the energy budget of both species, being only 2 to $5 \%$ of absorbed energy (AE) at all sizes (Table 3). An indicator of nutritional advantage to Pinctada maxima was RE as a percentage of $\mathrm{AE}$, this being significantly lower in $P$. maxima of $0.1 \mathrm{~g}$ dry soft tissue wt compared to $P$. margaritifera (Table 3). In both species there was a lack of relationship between absorption efficiency (abs.eff.) and body size that is in line with results for other bivalves (Thompson \& Bayne 1974, Griffiths \& King 1979a, Navarro \& Winter 1982, Stuart 1982), including tropical species (Klumpp \& Griffiths 1994)

In both Pinctada species the physiological processes of $C R$, respiration ( $R$ ) and excretion (E) increased exponentially with body size (Figs. 1 to 3 ). Values of the allometric exponents ranged from 0.44 and 0.56 for $\mathrm{R}, 0.60$ to 0.61 for $\mathrm{CR}$, and 0.64 and 0.79 for E. P. margaritifera had the lower exponent value in $R$ and $E$, indicating that rates of the 2 physiological processes declined more rapidly with increasing body size in this species compared with $P$. maxima. The only allometric exponent value for the respiration:body weight (R:W) relationship published for Pinctada species is 0.94 for P. martensii (Itoh 1976). Bayne \& Newell (1983) gave about 0.7 (range 0.4 to 1.0 ) as the mean value of allometric exponents for the $\mathrm{R}: \mathrm{W}$ relationship for a variety of marine molluscs. Thus the R:W exponent values for $P$. margaritifera and P. maxima from this study fall in the lower part of the recorded range, which means that size-specific metabolic rate of these species declines more rapidly with increasing body size than for the majority of bivalves. The CR:W exponent values for pearl oysters in the present study coincided with a mean value calculated for several filter feeding bivalves (i.e. mean $=0.62$, range 0.3 to 0.8 ; Bayne \& Newell 1983) The E:W relationship of filter feeding species is very variable (Bayne \& Newell 1983). In Mytilus edulis E:W was 0.48 to 1.48 (Bayne \& Scullard 1977 ) and the pearl oyster was within this range ( $P$. martensii 0.91, Itoh $1976 ; 0.64$ and 0.79 , this study).

To put the energy budgets for Pinctada margaritifera and $P$. maxima into perspective, comparable data for other Pinctada species, tropical/subtropical bivalves and temperate bivalves are presented in Table 5. Conditions such as food quantity and quality, and temperature vary across these different studies, so it is not possible to make precise comparisons. However, it is notable in Table 5 that $P$. margaritifera and $P$. maxima have high $C R, R, E$ and $S F G$ rates compared to most other bivalves for which data are available. Their CRs of $>10 \mathrm{l} \mathrm{h}^{-1}$ are not matched by any other bivalves, except for the temperate pearl oyster P. fucata martensii and the temperate bay scallop Argopecten irradians irradians. These high CR values may be related to proportionally large gill areas in these species, however there are no available data to support this. Their $\mathrm{R}$ values (i.e. aerobic metabolic rates) of $>0.85 \mathrm{ml} \mathrm{O}_{2} \mathrm{~h}^{-1}$ are only matched by the largest giant clam species, Tri- 


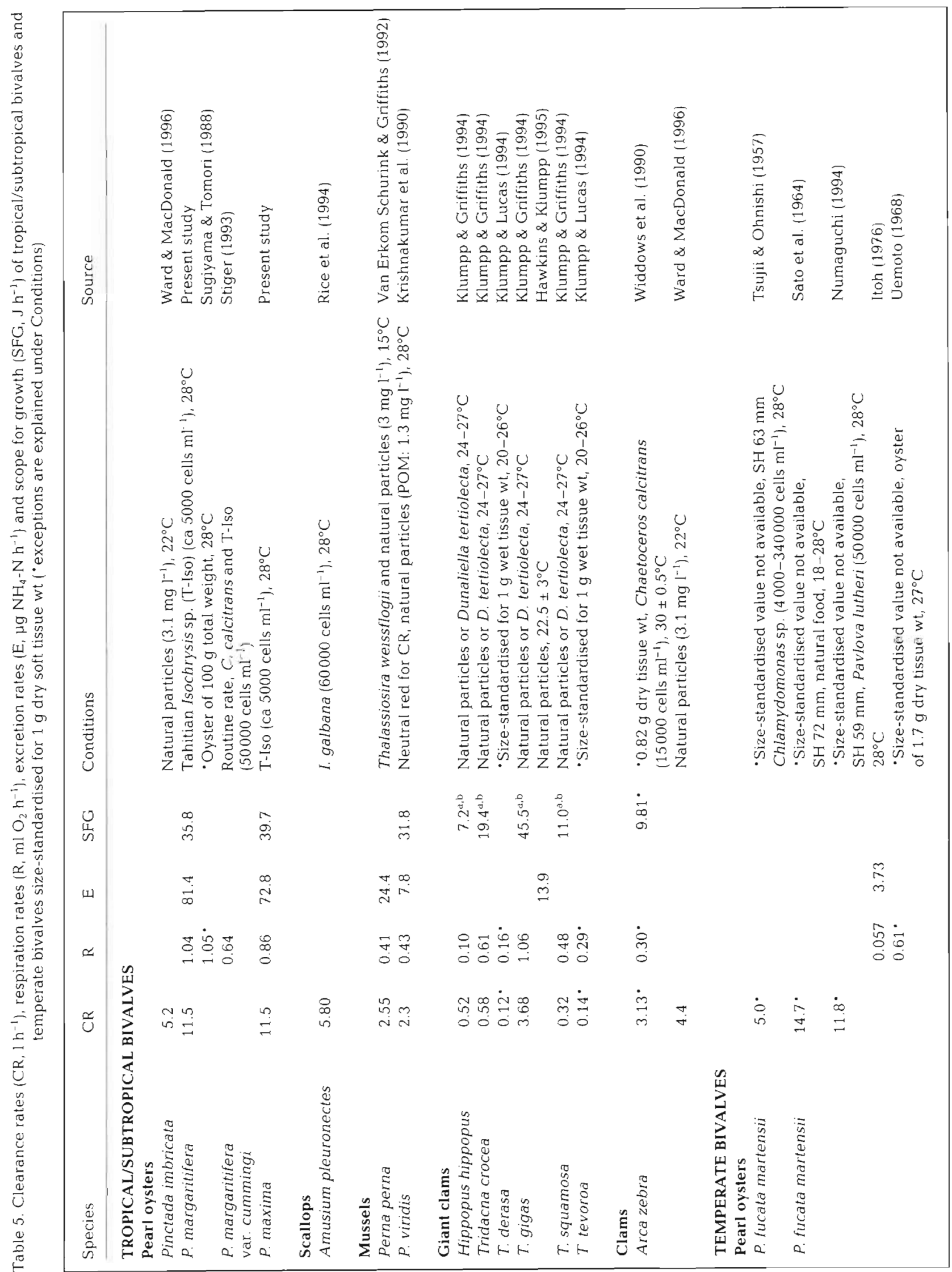




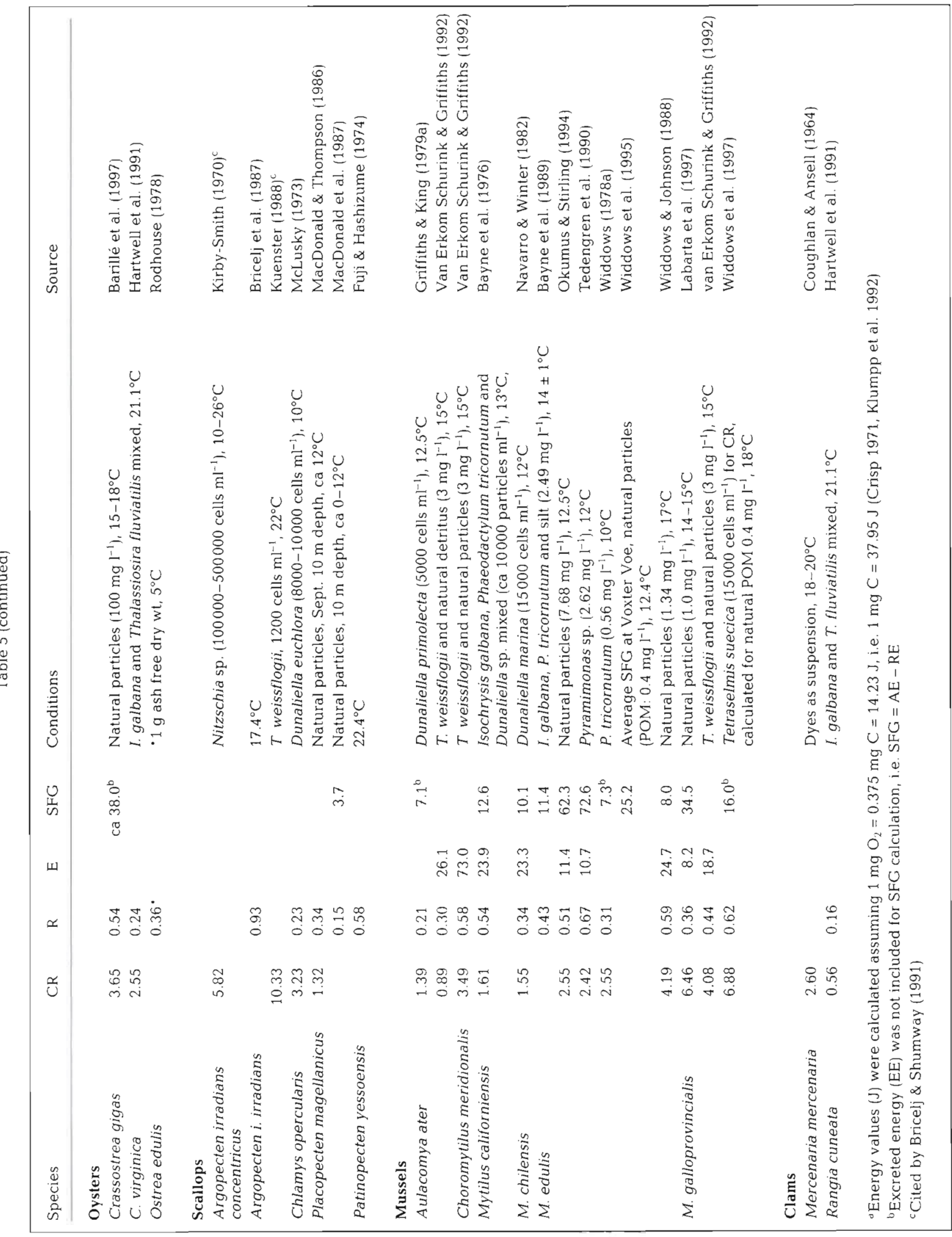


dacna gigas, and again the bay scallop. SFG values vary enormously depending on the quantity and quality of food available to the bivalve, e.g. the 5 values for Mytilus edulis in Table 5 range from 7.3 to $72.6 \mathrm{~J} \mathrm{~h}^{-1}$, a 10 -fold variation. However, the SFG values, 36 to $40 \mathrm{~J}$ $\mathrm{h}^{-1}$, for $P$. margaritifera and $P$. maxima on a relatively low cell concentration diet are only exceeded by the giant clam $T$. gigas and by $M$. edulis feeding at much higher cell concentrations and on highly nutritious particles.

Part of the difference between the rates of physiological processes and energy budgets of Pinctada margaritifera and $P$. maxima and those of the temperate bivalves may be due to the 10 to $15^{\circ} \mathrm{C}$ temperature difference of measurements. However, most of these differences would still seem to be significant even allowing for a $Q_{10}$ correction. The differences among tropical bivalves are not explained by temperature.

Only Tridacna gigas has a respiration rate and SFG that are comparable to Pinctada margaritifera and $P$. maxima. This giant clam species has a lower CR than the pearl oysters, but the clam supplements its suspension feeding by translocation of photosynthates from its symbiotic zooxanthellae (e.g. Klumpp \& Griffiths 1994, Lucas 1994). The clam achieves a comparably high SFG by a combination of heterotrophic and autotrophic nutrition. Moreover this supplementation of heterotrophy by autotrophy permits a number of giant clam species to attain maximum sizes that are much larger than those of pearl oysters and all other bivalves (Klumpp et al. 1992, Klumpp \& Griffiths 1994, Klumpp \& Lucas 1994).

Pinctada margaritifera and $P$. maxima are very energetic bivalves, in the sense of SFG and energy fluxes. Their suspension feeding rate is impressive, i.e. CR values of 50 to $100 \mathrm{l} \mathrm{h}^{-1}$, or 1000 to $2000 \mathrm{l} \mathrm{d}^{-1}$, in the largest individuals (Fig. 1). Large adult populations of these Pinctada species will process large volumes of surrounding seawater while suspension feeding, and thus potentially exhaust food supply. Hence, in their natural habitats, fast water current ensuring enough water exchange should be a requisite to maximise their energy gain and a factor determining their carrying capacities. In support of this, Saville-Kent (1890. cited by Gervis \& Sims 1992), Saville-Kent (1893) and Galtsoff (1933) reported that strong currents promoted growth in $P$. maxima and $P$. margaritifera galtsoffi. Currents promote growth in other bivalves by enhancing the flow of food and by downward mixing of particles into depleted boundary layers (Fréchette et al. 1989). Their high SFG values over a broad size range mean that pearl oysters should be comparatively fast growing among the marine bivalves employed in aquaculture. However the volume of water processed during suspension feeding could become an important and limiting factor in farming these oysters, although this does not appear to have been fully appreciated. In this situation, thousands of oysters kept in proximity may deplete phytoplankton levels for oysters downcurrent and furthermore produce large amounts of faeces and pseudofaeces. This may be particularly relevant to farming $P$. margaritifera in atoll lagoons where water currents and water exchange are often limited. Vacelet et al. (1996) described intensively cultured $P$. margaritifera in the Takapoto lagoon, French Polynesia, where high mortality of cultured and natural stocks of pearl oysters occurred during 1985 to 1986. These pearl oysters fed on a low stock of micro-organisms because of water replacement rate in the lagoon and high grazing pressure from the dense population of oysters.

Pinctada margaritifera and P. maxima have high suspension feeding rates, and intensive pearl culture clearly has the potential to exceed the available energy in ecosystems where there are low water replacement rates. The densities of cultured pearl oysters should be managed, taking account of water replacement conditions. Further studies are needed to model the carrying capacities of pearl farming sites, as has been undertaken for mussel farming (e.g. Rodhouse \& Roden 1987, Grant 1996).

Acknowledgements. We thank Mr Michael Crimp of Indian Pacific Pearls, Dr Paul Southgate of James Cook University and $\mathrm{Mr}$ Bruce Stevens of Reefarm for providing pearl oysters. We are also grateful to Dr David McKinnon of AIMS for his assistance with use of the particle counter. This research was funded by an Internal Research Allowance and Meritorious Research Grant from James Cook University. AIMS publication number 921 .

\section{LITERATURE CITED}

Barillé L, Prou J, Héral M, Razet D (1997) Effects of high natural seston concentrations on the feeding, selection, and absorption of the oyster Crassostrea gigas (Thunberg). J Exp Mar Biol Ecol 212:149-172

Bayne BL, Bayne CJ, Carefoot TC, Thompson RJ (1976) The physiological ecology of Mytilus californianus Conrad. 2. Metabolism and energy balance. Oecologia 22:211-228

Bayne BL, Brown DA, Burns $K$, Dixon DR, Ivanovici $A$, Livingstone DR, Lowe DM, Moore MN, Stebbing ARD, W1ddows J (1985) The effects of stress and pollution on marine animals. Praeger Press, New York

Bayne BL, Hawkins AJS, Navarro E, Iglesias IP (1989) Effects of seston concentration on feeding, digestion and growth in the mussel Mytilus edulis. Mar Ecol Prog Ser 55:47-54

Bayne BL, Newell RC (1983) Physiological energetics of marine molluscs. In: Wilbur KM et al. (eds) The Mollusca, Vol 4, Physiology, Part 1. Academic Press, New York, p 407-515

Bayne BL, Scullard C (1977) Rates of nitrogen excretion by species of Mytilus (Bivalvia: Mollusca). J Mar Biol Assoc UK 57:355-369

Bricelj VM, Epp J, Malouf RE (1987) Comparative physılogy 
of young and old cohorts of bay scallops Argopecten irradians (Lamarck): mortality, growth and oxygen consumption. J Exp Mar Biol Ecol 112:73-91

Bricelj VM, Shumway S (1991) Physiology: energy acquisition and utilization. In: Shumway SE (ed) Developments in aquaculture and fisheries science, Vol 21, Scallops: biology, ecology and aquaculture. Elsevier, Amsterdam, p 305-346

Coeroli M (1983) Pinctada margaritifera. In: Milieu lagunaire. Etat des connaissances. Pêche Document No. 7. EVAAM Service de la Mer, Polynésie Française, p 1-20

Coeroli M, De Gaillande D, Landret JP (1984) Recent innovations in cultivation of molluscs in French Polynesia. Aquaculture 39:45-67

Conover RJ (1966) Assimilation of organic matter by zooplankton. Limnol Oceanogr 18:673-678

Coughlan J, Ansell DA (1964) A direct method for determining the pumping rate of siphonate bivalves. J Cons Int Explor Mer 29:205-213

Crisp DJ (1971) Energy flow measurements. In: Holme NA, McIntyre AD (eds) Methods for the study of marine benthos. Int Biol Prog 16, Blackwell, Oxford, p 197-323

Fréchette M, Butman CA, Geyer WR (1989) The importance of boundary-layer flows in supplying phytoplankton to the benthic suspension feeder, Mytilus edulis L. Limnol Oceanogr 34:19-36

Fuji A, Hashizume M (1974) Energy budget for a Japanese common scallop, Patinopecten yessoensis (Jay), in Mutsu Bay. Bull Fac Fish Hokkaido Univ 25:7-19

Galtsoff PS (1933) Pearl and Hermes reef, Hawail hydrographical and biological observations. Bull Bishop Mus Honolulu 107:3-49

Gervis MH, Sims NA (1992) The biology and culture of pearl oysters (Bivalvia: Pteriidae). ICLARM Stud Rev 21:49

Grant J (1996) The relationship of bioenergetics and the environment to the field growth of cultured bivalves. J Exp Mar Biol Ecol 200:239-256

Griffiths CL, Griffiths RJ (1987) Bivalvia. In: Pandian TJ, Vernberg FJ (eds) Animal energetics, Vol 2, Bivalvia through Reptilia. Academic Press, New York, p 1-87

Griffiths CL, King JA (1979a) Some relationships between size, food availability and energy balance in the ribbed mussel Aulacomya ater. Mar Biol 51:141-149

Griffiths CL, King JA (1979b) Energy expended on growth and gonad output in the ribbed mussel Aulacomya ater. Mar Biol 53:217-222

Hartwell SI, Wright DA, Takacs R, Hocutt CH (1991) Relative respiration and feeding rates of oyster and brackish water clam in variously contaminated waters. Mar Pollut Bull 22: 191-197

Hawkins AJS, Klumpp DW (1995) Nutrition of the giant clam Trldacna gigas (L.). Il. Relative contnbutions of filter-feeding and the ammonium-nitrogen acquired and recycled by symbiotic alga towards total nitrogen requirements for tissue growth and metabolism. J Exp Mar Biol Ecol 190: 291-301

Hildreth DI, Crisp DJ (1976) A corrected formula for calculation of filtration rate of bivalve molluscs in an experimental flowing system. J Mar Biol Assoc UK 56:111-120

Itoh K (1976) Relations of oxygen consumption and ammonia nitrogen excreted to body size and to water temperature in the adult of pearl oyster Pinctada fucata. Bull Natl Pearl Res Lab 20:2254-2275 (in Japanese)

Jørgensen CB (1990) Bivalve filter feeding: hydrodynamics, bioenergetics, physiology and ecology. Olsen \& Olsen, Fredensborg

Jørgensen CB (1996) Review: bivalve filter feeding revisited. Mar Ecol Prog Ser 142:287-302
Kailola PJ, Williams MJ, Stewart PC, Reichelt RE, Mcnee A Grieve C (1993) Australian fisheries resources. Bureau of Resource Sciences, Department of Primary Industries and Energy, and Fisheries Research and Development Corporation, Canberra, p 87-89

Klumpp DW, Bayne BL, Hawkins AJS (1992) Nutrition of the giant clam Tridacna gigas (L.). I. Contribution of filter feeding and photosynthates to respiration and growth. J Exp Mar Biol Ecol 155:105-122

Klumpp DW, Griffiths CL (1994) Contributions of phototrophic and heterotrophic nutrition to the metabolic and growth requirements of four species of giant clam (Tridacnidae). Mar Ecol Prog Ser 115:103-115

Klumpp DW, Lucas JS (1994) Nutritional ecology of the giant clams Tridacna tevoroa and $T$ derasa from Tonga: influence of light on filter-feeding and photosynthesis. Mar Ecol Prog Ser 107:147-156

Krishnakumar PK, Asokan PK, Pillai VK (1990) Physiological and cellular responses to copper and mercury in the green mussel Perna viridis (Linnaeus). Aquat Toxicol 18:163-174

Labarta U, Fernandez-Reiriz MJ, Bābarro JMF (1997) Differences in physiological energetics between intertidal and raft cultivated mussels Mytilus galloprovincialis. Mar Ecol Prog Ser 152:167-173

Lucas JS (1994) The biology, exploitation, and mariculture of giant clams (Tridacnidae). Rev Fish Sci 2:181-223

MacDonald BA, Thompson RJ (1986) Influence of temperature and food availability on the ecological energetics of the giant scallop Placopecten magellanicus. III. Physiological ecology, the gametogenic cycle and scope for growth. Mar Biol 93:37-48

MacDonald BA, Thompson RJ, Bayne BL (1987) Influence of temperature and food avallability on the ecological energetics of the giant scallop Placopecten magellanicus. IV Reproductive effort, value and cost. Oecologia 72:550-556

McLusky DS (1973) The effect of temperature on the oxygen consumption and filtration rate of Chlamys (Aequipecten) percularis (L.) (Bivalvia). Ophelia 10:114-154

Navarro JM, Winter JE (1982) Ingestion rate, assimilation efficiency and energy balance in Mytilus chilensis in relation to body size and different algal concentrations. Mar Biol 67:255-266

Numaguchi K (1994) Effect of water temperature on the filtration rate of Japanese pearl oyster, Pinctada fucata martensii. Suisanzoshoku 41:1-6

Okumus I, Stirling HP (1994) Physiological energetics of cultivated mussel (Mytilus edulis) populations in two Scottish west coast sea lochs. Mar Biol 119:125-131

Rice MA, Rheault RB, Perez MS, Perez VS (1994) Experimental culture and particle filtration by Asian moon scallops, Amusium pleuronectes. Asian Fish Sci 7:179-185

Rodhouse PG (1978) Energy transformations by the oyster Ostrea edulis L. in a temperate estuary. J Exp Mar Biol Ecol 34:1-22

Rodhouse PG, Roden CM (1987) Carbon budgets for a coastal inlet in relation to intensive cultivation of suspensionfeeding bıvalve molluscs. Mar Ecol Prog Ser 36:225-236

Sagara J, Takemura Y (1960) Studies on the age determination of the silver-lip pearl oyster, Pinctada maxima (Jameson). Bull Tokai Reg Fish Res Lab 27:7-14

Sato T, Matsumoto S, Horiguchi Y, Tsujii T (1964) Filtering and feeding rate of the pearl oyster Pteria (Pinctada) martensii Dunker determined with crude silicate as an indicator. Bull Jpn Soc Sci Fish 30:717-722 (in Japanese)

Saville-Kent W (1893) The Great Barrier Reef of Australia; its products and potentialities, Chap V, Pearl and pearl-shell fisheries. WH Allen \& Co, London, p 204-224 
Sims NA (1993) Size, age and growth of the black-lip pearl ayster, Pinctada margaritifera (L.) (Bivalvia; Pteriidae). J Shellfish Res 12:223-228

Solorzano L (1969) Determination of ammonia in natural waters by the pheno- hypochlorite method. Limnol Oceanogr 14:799-801

Stiger V (1993) Évaluation de la consommation d'oxygène de l'huitre perlicre. Pinctada margaritifera (L.) var cumingii (Jameson). Mémoire de DEA, Université Française du Pacifique, p 38

Stuart V (1982) Absorbed ration, respiratory costs and resultant scope for growth in the mussel Aulacomyd ater (Molina) fed on a diet of kelp detritus of different ages Mar Biol Lett 3:289-306

Sugiyama A, Tomori A (1988) Oxygen consumption of blacklip pearl oyster. Suisanzoshoku 3:121-125

Tedengren M, Andre C, Johannesson K, Kautsky N (1990) Genotypic and phenotypic differences between Baltic and North Sea populations of Mytilus edulis evaluated through reciprocal transplantations. 3. Physiology. Mar Ecol Prog Ser 59:221-227

Thompson RJ, Bayne BL (1974) Some relationships between growth, metabolism and food in the mussel Mytilus edulis L. Mar Biol 27:317-326

Tsujii T, Ohnishi K (1957) Studies on the filtration and food requirements by pearl oysters. 1) On the water filtration. Bull Natl Pearl Res Lab 3:194-201 (in Japanese)

Uemoto $\mathrm{H}$ (1968) Relationship between oxygen consumption by the pearl oyster and its environmental temperature. Bull Natl Pearl Res Lab 13:1617-1623 (in Japanese)

Vacelet E, Arnoux A. Thomassin B (1996) Particulate material as an indicator of pearl-oyster excess in the Takapoto lagoon (Tuamotu, French Polynesia). Aquaculture 144: $133-148$

van Erkom Schurink C, Griffiths CL (1992) Physiological energetics of four South African mussel species in relation to body size, ration and temperature. Comp Biochem

Editorial responsibility: Otto Kinne (Editor),

Oldendorf/Luhe, Germany
Physiol 101A:779-789

Ward JE, MacDonald BA (1996) Pre-ingestive feeding behaviors of two sub-tropical bivalves (Pinctada imbricata and Arca zebra): responses to an acute increase in suspended sediment concentration. Bull Mar Sci 59:417-432

Warren CE, Davis GE (1967) Laboratory studies on the feeding, bioenergetics, and growth of fish. In: Gerking SD (ed) The biological basis of freshwater fish production. Blackwell Scientific Publications, Oxford, p 175-214

Whyte JNC (1987) Biochemical composition and energy content of six species of phytoplankton used in mariculture of bivalves. Aquaculture 60:231-241

Widdows J (1978a) Combined effects of body size, food concentration and season on the physiology of Mytilus edulis. J Mar Biol Assoc UK 58:109-124

Widdows J (1978b) Physiological indices of stress in Mytilus edulis. J Mar Biol Assoc UK 58:125-142

Widdows J (1985) Physiological procedures. In: Bayne BL et al. (eds) The effects of stress and pollution on marine animals, Chap 7. Praeger Press, New York, p 161-178

Widdows J, Burns KA, Menon NR, Page DS, Soria S (1990) Measurement of physiological energetics (scope for growth) and chemical contaminants in mussels (Arca zebra) transplanted along a contamination gradient in Bermuda. J Exp Mar Biol Ecol 138:99-117

Widdows J, Donkin P, Evans SV, Salkeld PN, Franklin A, Law R, Waldock MJ (1995) Scope for growth and contaminant levels in North Sea mussels (Mytilus edulis). Mar Ecol Prog Ser 127:131-148

Widdows J, Johnson D (1988) Physiological energetics of Mytilus edulis: scope for growth. Mar Ecol Prog Ser 46: $113-121$

Widdows J, Nasci C, Fossato VU (1997) Effects of pollution on the scope for growth of mussels (Mytilus galloprovincialss) from the Venice Lagoon, Italy. Mar Environ Res 43:69-79

Zar JH (1996) Biostatistical analysis, 3rd edn. Prentice Hall, Englewood Cliffs, NJ

Submitted: October 21, 1997; Accepted: June 2, 1998

Proofs received from author(s): July 27, 1998 